\title{
Kesalahan Siswa Dalam Mengidentifikasikan dan Menggambarkan Diagram Gaya
}

\author{
Uulia 'Iffa ${ }^{1}$, Edi Supriana ${ }^{1}$, Sutopo ${ }^{1}$ \\ ${ }^{1}$ Pendidikan Fisika-Universitas Negeri Malang
}

\begin{tabular}{l}
\hline \hline INFO ARTIKEL \\
\hline Riwayat Artikel: \\
Diterima: 09-04-2019 \\
Disetujui: $15-07-2019$ \\
\hline
\end{tabular}

\section{Kata kunci:}

mastery of concepts; style identification; style diagram; student error; penguasaan konsep; identifikasi gaya; diagram gaya: kesalahan siswa

\section{ABSTRAK}

\begin{abstract}
Conceptual understanding is one indicator of success in learning. Mastery of concepts is seen when someone can solve a problem. This study aims to see student's mistakes in identifying and describing diagrams of force, particle dynamics. This type of research uses quantitative descriptive research with survey methods, research subjects amounted to 97 students. The technique of collecting data in the form of reasoned multiple choice tests with alpha cronbach is 0,68 . The results of the study show that almost all students experience errors in identifying and describing the style diagrams that work on a system. Common mistakes that cause students to fail to work on problems well are because students are more likely to memorize mathematical formulations of a concept, without knowing how the concept is formed.
\end{abstract}

\begin{abstract}
Abstrak: Pemahaman konsep yang baik merupakan salah satu indikator keberhasilan dalam pembelajaran. Penguasaan konsep terlihat ketika seseorang dapat memecahkan suatu permasalahan. Penelitian ini bertujuan untuk melihat kesalahan siswa dalam mengidentifikasikan dan menggambarkan diagram gaya suatu permasalahan fisika materi dinamika partikel. Penelitian ini merupakan penelitian deskriptif kuantitatif dengan metode survei. Subjek penelitian berjumlah 97 orang. Teknik pengumpulan data berupa tes pilihan ganda beralasan dengan alpha Cronbach 0,68. Hasil penelitian menunjukkan hampir seluruh siswa mengalami kesalahan dalam mengidentifikan dan menggambarkan diagram gaya yang bekerja pada suatu sistem. Kesalahan umum yang menyebabkan siswa gagal mengerjakan soal dengan baik dikarenakan siswa lebih cenderung menghapal perumusan matematis dari suatu konsep, tanpa mengetahui bagaimana konsep terbentuk.
\end{abstract}

\author{
Alamat Korespondensi: \\ Uulia 'Iffa \\ Pendidikan Fisika \\ Universitas Negeri Malang \\ Jalan Semarang 5 Malang \\ E-mail: uulia.iffa@gmail.com
}

Hukum Newton merupakan fundamental ilmu dalam mekanika klasik. Oleh karena itu, penting bagi siswa untuk memahami dengan baik hukum Newton dan menerapkannya dalam memecahkan masalah. Untuk dapat menerapkan hukum Newton siswa perlu terampil dalam mengidentifikasi gaya-gaya yang bekerja pada benda. Namun, mengidentifikasi gaya-gaya yang bekerja pada suatu benda secara lengkap bukanlah sesuatu yang mudah mengingat kehadiran gaya-gaya tersebut ada yang dengan mudah dikenali oleh siswa dan ada yang tidak (Januarifin et all, 2018). Contoh, ketika diminta mengidentifikasi gaya yang bekerja pada meja diam yang didorong sehingga bergerak, sebagian besar siswa hanya menyebut gaya $\mathbf{F}$. Jarang siswa menyebutkan gaya lain yang dapat memengaruhi gerak benda seperti gaya gravitasi, normal dan gesek (Barniol \& Zavala, 2014a). Oleh karena itu, siswa perlu memahami bagaimana mengidentifikasi gaya-gaya dapat bekerja pada suatu benda.

Selain mengidentifikasi gaya-gaya yang bekerja pada suatu benda, siswa juga perlu melakukan representasi seperti gambar, diagram, dan persamaan matematis (Rosengrant, Van Heuvelen, \& Etkina, 2009). Diagram dalam fisika meliputi diagram benda bebas atau free body diagram. Free body diagram merupakan diagram terpisah untuk tiap benda atau sistem yang memperlihatkan semua gaya yang bekerja pada tiap benda atau sistem, atau diagram yang menunjukkan arah dan besar gaya yang bekerja pada suatu benda tertentu (Saepuzaman et al., 2014). Menguraikan gaya-gaya pada dua sumbu tegak lurus juga termasuk bagian penting diagram benda. (Barniol \& Zavala, 2014b; Flores, Kanim, \& Kautz, 2004; Heckler \& Scaife, 2015; Nguyen \& Meltzer, 2003). Penggunaan diagram benda bebas dapat memudahkan siswa dalam menganalisis dan menyelesaikan suatu permasalahan kompleks (Ayesh et all., 2010). Siswa lebih mudah menentukan resultan gaya yang bekerja jika mereka mampu menguraikan gaya dan diagram benda bebas pada sistem dengan baik. 
Mengidentifikasi gaya-gaya yang bekerja pada suatu sistem erat kaitannya dengan menggambarkan diagram benda bebas. Siswa yang mampu mengidentifikasi gaya-gaya yang bekerja pada suatu benda akan dengan mudah membuat representasi gayagaya tersebut ke dalam bentuk gambar dan diagram. Mengingat pentingnya penggunaan diagram yang telah dipaparkan pada bagian diatas, diperlukan penelitian lebih lanjut untuk mengetahui pemahaman siswa dalam mengidentifikasi dan menggambarkan diagram benda bebas pada suatu sistem.

Sejauh ini, penelitian yang secara rinci menjelaskan keterkaitan kesalahan siswa dalam mengidentifikasi dan menggambarkan diagram gaya masih jarang dilakukan. Pada umumnya, penelitian yang berkembang membahas kesulitan siswa dalam menganalisis dan memecahkan permasalahan hukum Newton secara keseluruhan (Ishimoto, Davenport, \& Wittmann, 2017). (Saepuzaman et al., 2014) menyatakan siswa cenderung lebih senang bekerja secara matematis, hal ini menandai bahwa siswa masih kurang memahami materi dengan baik dan menyebabkan terjadinya miskonsepsi. Gaguk (2017) menyatakan banyaknya miskonsepsi siswa dalam menyelesaikan permasalahan hukum Newton terutama pada konsep dasar dan dalam hal menentukan besar resultan gaya yang bekerja pada suatu. Januarifin (2018) menemukan terdapat kesulitan-kesulitan yang dialami siswa dalam memecahkan permasalahan yang berkaitan hukum Newton, baik hukum I, II, ataupun III Newton. Ishimoto (2018) melakukan penelitian yang berkaitan dengan pemahaman konsep gaya dan gerak dengan soal Force and Motion Conceptual Evaluation (FMCE) terhadap mahasiswa beda negara dan menemukan bahwa faktor kebudayan suatu negara juga memengaruhi pola pikir siswa, kemudian dalam penelitiannya menemukan banyaknya siswa yang melakukan kesalahan dalam menyelesaikan permasalahan fisika (Ishimoto, et al, 2017). Oleh karena itu, peneliti tertarik untuk melakukan penelitian tentang diagnosis kesalahan siswa dalam mengidentifikasi dan menggambarkan diagram gaya.

\section{METODE}

Penelitian ini bertujuan untuk mengetahui kesalahan-kesalahan yang dialami oleh siswa dalam menganalisis jenis-jenis gaya dan menggambarkan diagram gaya ketika mengerjakan permasalahan fisika dalam kehidupan sehari-hari. Penelitian dilakukan di salah satu SMA Negeri di kota Malang tahun ajaran 2018/2019, semester genap. Subjek penelitian terdiri dari 97 siswa dari kelas X MIPA.

Instrumen soal yang digunakan berupa tes pilihan ganda beralasan, terdiri dari lima butir soal. Lima butir soal memiliki karakteristik seperti yang ditunjukkan oleh tabel 1. Soal yang dipilih merupakan soal dasar yang dapat menunjukkan kesalahankesalahan siswa dalam mengidentifikasi dan menggambarkan diagram benda bebas. Skor yang diperoleh siswa jika jawaban benar dan alasan benar adalah 1. Jika jawaban benar tetapi alasan salah, jawaban dan alasan salah siswa mendapatkan poin 0 .

Data dianalisis dengan cara melihat persentase setiap jawaban siswa. Setelah diketahui nilai persentase setiap pilihan jawaban, kesalahan yang dilakukan oleh siswa akan dianalisis berdasarkan jawaban dan alasan yang dimiliki oleh siswa. Soal yang ditambilkan merupakan soal dengan substansi dasar dalam penggambaran diagram sehingga digunakan soal dengan nomor 1,2 , dan 4.

Tabel 1. Karakteristik Soal Mengidentifikasi dan Menggambarkan Diagram Gaya

\begin{tabular}{cl}
\hline Nomor Soal & \multicolumn{1}{c}{ Karakteristik Soal } \\
\hline 1 & $\begin{array}{l}\text { Mengidentifikasi gaya yang bekerja pada benda yang diberikan gaya P pada satu } \\
\text { sistem terdiri dari duabalok dengan massa berbeda melalui diagram gaya. }\end{array}$ \\
\hline 2,3 & Mengidentifikasi gaya-gaya yang bekerja pada suatu benda \\
\hline 4,5 & Menganalisis hubungan antara, gaya, massa, dan percepatan pada gerak lurus \\
\hline
\end{tabular}

\section{HASIL}

Instrumen soal yang dikerjakan oleh siswa menunjukkan tingkat pemahaman siswa pada suatu materi. Siswa mengerjakan soal dengan indikator tersaji pada tabel 1 yang bertujuan untuk mengetahui kesalahan siswa dalam mengidentifikasi dan menggambarkan diagram gaya. Berdasarkan hasil penelitian yang telah dilakukan, diperoleh hasil seperti yang tertera pada tabel 2. Masih banyak siswa yang melakukan kesalahan selama menyelesaikan soal yang diberikan. Hal ini terbukti dari jumlah siswa yang mampu menjawab benar setiap soal. Dari empat soal yang disajikan, persentase siswa menjawab benar paling besar hanya $15,5 \%$.

Tabel 2. Karakteristik Soal dan Persentase Jawaban Siswa

\begin{tabular}{lc}
\hline \multicolumn{1}{c}{ Karakteristik Soal } & Persentase Siswa Menjawab Benar \\
\hline $\begin{array}{l}\text { Mengidentifikasi gaya yang bekerja pada benda yang diberikan gaya P pada satu } \\
\text { sistem terdiri dari dua balok dengan massa berbeda melalui diagram gaya. }\end{array}$ & $8,24 \%$ \\
\hline Mengidentifikasi gaya-gaya yang bekerja pada suatu benda. & $15,5 \%$ \\
\hline Menganalisis hubungan antara, gaya, massa, dan percepatan pada gerak lurus & $8,4 \%$ \\
\hline
\end{tabular}


Nilai persentase jawaban benar siswa yang kecil, memperlihatkan siswa mengalami kesalahan dalam mengerjakan setiap soalnya. Kesalahan yang dimiliki oleh siswa dapat dilihat dari pilihan jawaban yang mereka pilih dan juga dari alasan yang mereka berikan. Terlihat untuk setiap nomor soal, untuk masing-masing pilihan memiliki persentase masing-masing. Persentase setiap pilihan soal tergambar pada tabel 3 .

Tabel 3. Sebaran Jawaban Siswa untuk Setiap Indikator

\begin{tabular}{ccccccc}
\hline \multirow{2}{*}{ Indikator } & \multicolumn{7}{c}{ Jawaban Pilihan Ganda Siswa } \\
\cline { 2 - 7 } & $\mathbf{A}$ & $\mathbf{B}$ & $\mathbf{C}$ & $\mathbf{D}$ & $\mathbf{E}$ & Tidak dijawab \\
\hline 1 & $4,1 \%$ & $54,6 \%$ & $24,7 \%$ & $21,1 \%$ & $8,24 \%$ & $4,1 \%$ \\
\hline 2 & $39,2 \%$ & $15,5 \%$ & $13,4 \%$ & $16,5 \%$ & $6,2 \%$ & $7,2 \%$ \\
\hline 3 & $4,2 \%$ & $2,1 \%$ & $54,2 \%$ & $33,3 \%$ & $6,25 \%$ & \\
\hline 4 & $8 \%$ & $42,3 \%$ & $29,9 \%$ & $2,1 \%$ & - & $11,3 \%$ \\
\hline 5 & $56,3 \%$ & $8,3 \%$ & $12,5 \%$ & $18,75 \%$ & $4,2 \%$ & - \\
\hline
\end{tabular}

\section{PEMBAHASAN}

\section{Kesalahan Siswa Mengenali Jenis dan Arah Gaya}

Terdapat banyak gaya dalam ilmu dinamika partikel, seperti gaya normal, gaya gesek, gaya tarik-gaya dorong, dan gaya gravitasi. Kasus soal yang sering diminta kepada siswa yaitu menyelesaikan permasalahan kompleks ketika dua benda berdempetan seperti yang terlihat pada gambar 1 . Soal pada gambar 1 merupakan soal dengan indikator pertama yang ada pada tabel 1.

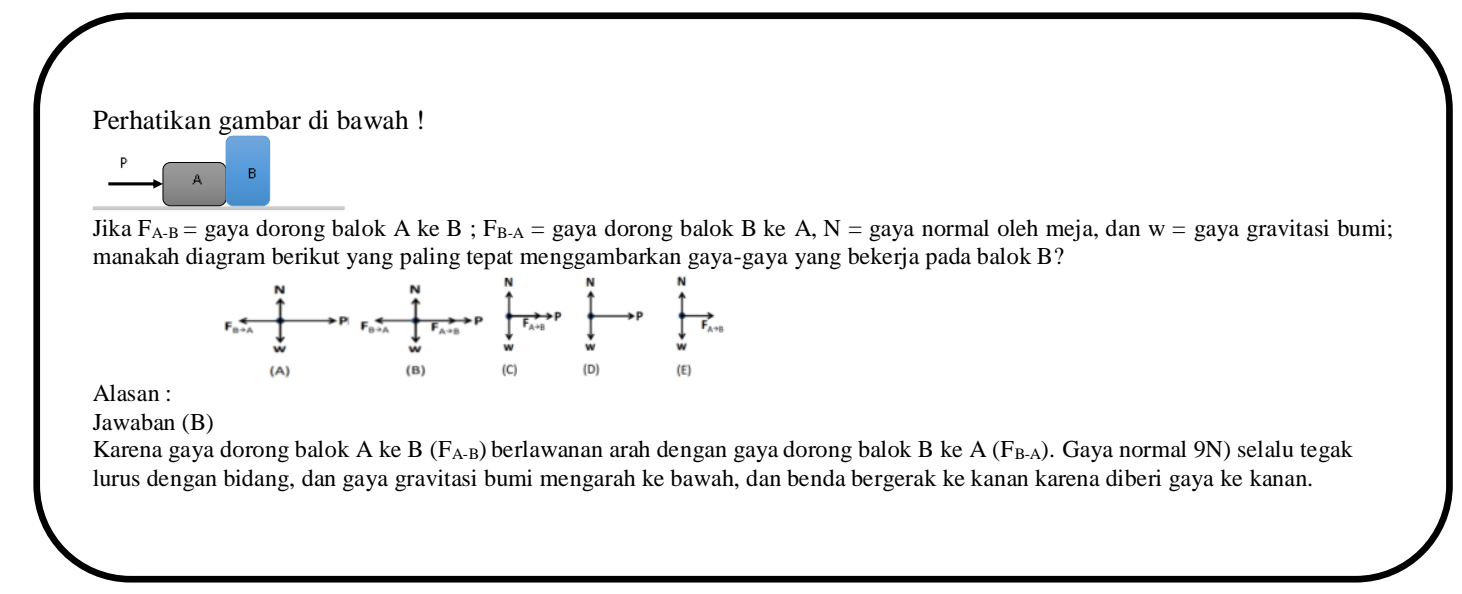

\section{Gambar 1. Salah Satu Contoh Soal dan Jawaban Siswa tentang Mengidentifikasi Gaya yang Bekerja pada Dua Balok Berdempetan}

Soal pertama berkaitan dengan mengidentifikasi gaya yang bekerja pada sistem diam seperti terlihat pada gambar 1 beserta salah satu contoh jawaban siswa. Pada soal tersebut diminta siswa mengidentifikasi dan menggambarkan gaya-gaya yang bekerja pada balok B. Persentase siswa yang menjawab benar soal yang tertera pada gambar 1 hanya $8,24 \%$ dari total keseluruhan siswa. 50\% siswa menjawab dengan jawaban (B), jawaban benar untuk soal di atas adalah (E). Siswa memilih poin (B) karena siswa beranggapan bahwa pada balok B gaya dorong $\mathrm{P}$ yang arahnya ke kanan masih bekerja dan gaya dorong $\mathbf{F}_{\mathrm{B} \rightarrow \mathrm{A}}$ juga bekerja pada balok B. Sebenarnya, gaya yang bekerja pada balok B, searah vertikal hanya gaya normal yang arahnya tegak lurus bidang sentuh dan gaya gravitasi bumi yang memiliki arah selalu menuju pusat bumi. gaya pada sumbu horizontal yang bekerja hanyalah gaya dorong balok A ke balok B, $\mathbf{F}_{\mathrm{A} \rightarrow \mathrm{B}} . \mathbf{F}_{\mathrm{B} \rightarrow \mathrm{A}}$ secara langsung telah disebutkan dalam soal adalah gaya dorong balok $\mathrm{B}$ ke balok A jadi tidak bekerja pada balok B, melainkan bekerja pada balok A. Gaya dorong P hanya bekerja pada balok A dan tidak bekerja pada balok B.

Dalam hal ini, siswa masih memiliki kesalahan konsep tentang pengidentifikasian gaya yang bekerja pada suatu sistem. Siswa cenderung langsung menggunakan pengetahuan awal yang mereka miliki kedalam permasalahan tanpa menelaah lebih lanjut apakah bentuk permasalahannya sama atau tidak (Resbiantoro, 2017; Saepuzaman et al., 2014). Konsep yang harus dimiliki siswa dalam menyelesaikan permasalahan seperti pada gambar 1 di atas, yaitu siswa harus menguasai jenis-jenis gaya dan bagaimana arah gaya yang bekerja benda. Selain harus memahami konsep, siswa juga dituntut dapat mengubah bahasa permasalahan yang ada kedalam bahasa fisika (Brookes \& Etkina, 2009). 
Secara umum, siswa tidak dapat menentukan konsep yang tersirat pada soal, langkah apa yang harus pertama kali mereka lakukan ketika diberikan soal. Pemecahan permasalahan juga menuntut siswa harus bekerja secara sistematis, sesuai dengan urutan-urutan yang ada (Wechsler et al., 2018). Kenyataan yang ada siswa terlalu malas untuk membaca informasi penting pada soal, mereka langsung mengerjakan dengan hanya melihat gambar dan pertanyaan yang ada (Januarifin et all., 2018).

\section{Kesalahan Siswa Ketika Memproyeksikan Gaya}

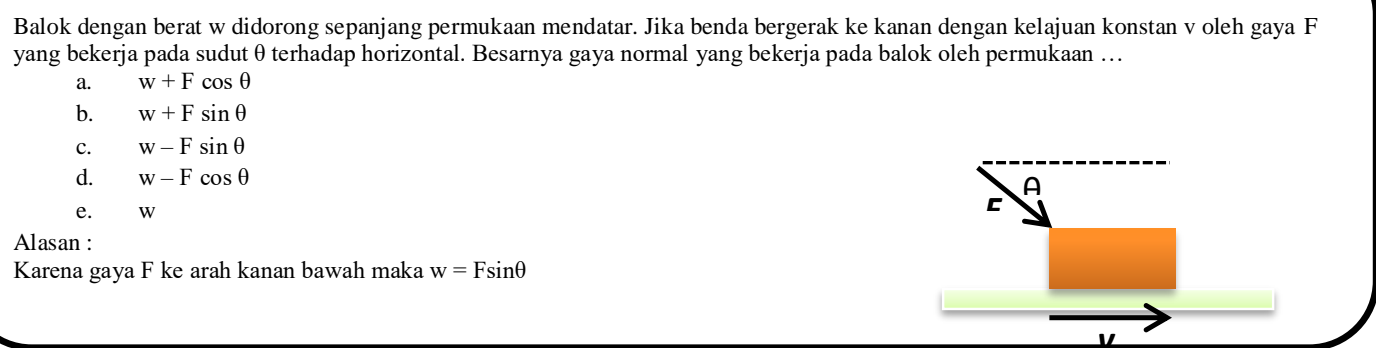

\section{Gambar 2. Salah Satu Contoh Soal dan Jawaban Siswa tentang Mengidentifikasikan Gaya yang memiliki Sudut Tertentu}

Soal kedua berkaitan dengan gaya dorong yang diberikan sudut tertentu terhadap bidang miring. Pada gambar 2 di atas, disebutkan balok dengan berat w didorong sepanjang permukaan mendatar, benda bergerak ke kanan dengan kelajuan konstan oleh gaya $\mathrm{F}$ yang bekerja pada sudut $\theta$ terhadap horizontal, dan siswa diminta menentukan gaya normal yang bekerja pada balok oleh permukaan. Siswa yang menjawab benar soal di atas berkisar 15,5\% dari keseluruhan siswa. hampir 20\% siswa menjawab (C), $15 \%$ siswa menjawab (A), $10 \%$ siswa menjawab (D) dan 39,5\% siswa menjawab jawaban (E). Pilihan jawaban yang benar adalah poin (B). Siswa diminta mampu menguasai jenis-jenis gaya, mampu menganalisis soal, dan mampu menggunakan persamaan matematis hukum Newton dengan baik.

Terlihat pada soal diatas bahwa balok bergerak ke kanan dengan kelajuan konstan, yang artinya jika kelajuan konstan maka nilai percepatan balok adalah nol (Serway \& Jewett, 2006). Kemudian, siswa diminta mengidentifikasikan gaya yang bekerja pada balok dan menggambarkan bagaimana gaya tersebut memengaruhi gerak balok. Gaya-gaya yang bekerja pada balok dapat dilihat pada gambar, karena gambar bersentuhan dengan lantai, maka harusnya balok memiliki gaya normal (N), dan juga terdapat gaya berat yang arahnya selalu menuju pusat bumi disebut gaya gravitasi bumi (w). Gaya normal dan gaya gravitasi bumi bekerja searah sumbu vertikal permukaan. Gaya yang bekerja pada sumbu horizontal harus diidentifikasi dari gaya dorong yang diberikan dengan sudut tertentu. Untuk kasus ini diperlukan proyeksi gaya searah sumbu vertikal dan sumbu horizontal. Karena sudut $\theta$ berada pada bagian atas, maka diperoleh F $\cos \theta$ untuk sumbu horizontal, dan Fsin $\theta$ untuk sumbu vertikal (Cummings et al., 2004). Siswa juga sering kesulitan dalam menentukan proyeksi gaya dengan sudut terhadap sumbu horizontal. Mereka kurang bias menentukan kapan pada sumbu vertikal $\sin \theta$, kapan pada sumbu horizontal $\cos \theta$, dan sebaliknya (Maries \& Singh, 2013; Morphew et al., 2015)

Setelah mengetahui gaya-gaya yang bekerja terhadap masing-masing bidang, dilanjutkan dengan penggunaan matematis hukum II Newton $\sum \mathbf{F}=$ m.a. Gaya yang diidentifikasi terhadap masing-masing bidang, maka untuk memudahkan menyelesaikan permasalahan, soal dianalisis sesuai permintaan soal. Pada soal diminta menentukan gaya normal balok terhadap permukaan, dan gaya normal terletak pada bidang vertikal, maka cukup untuk mengerjakan terhadap bidang vertikal $\sum \mathbf{F}_{\mathbf{y}}=\mathrm{m} . \mathbf{a}$. Siswa sering melupakan makna tanda sigma pada persamaan hukum II Newton, mereka langsung menyatakan gaya sama dengan massa dikalikan dengan percepatan. Namun, maksud dari kata sigma pada persamaan adalah jumlah gaya yang memengaruhi gerak benda. Sebagaimana yang diketahui, bahwa gaya merupakan besaran vektor, gaya-gaya searah dijumlahkan dan gaya berlawanan arah dikurangi. Siswa sering salah dalam mensubtitusikan gaya yang bekerja, bagian mana yang harus dijumlah atau dikurangi (Barniol \& Zavala, 2014; Heckler \& Scaife, 2015).

Distrubusi jawaban siswa untuk soal pada gambar 4 yang mampu menjawab dengan benar hanya $8 \%$ dari total keseluruhan siswa yang mengikuti tes. Pilihan jawaban siswa tersebar merata untuk poin (A), (B), (C), dan (D). Jawaban yang benar untuk soal pada gambar 4 adalah poin $(\mathrm{A}), \mathbf{T}=\mathbf{W}$. Rata-rata siswa menjawab dengan pilihan jawaban (B) dikarenakan sudut yang dibentuk oleh tali $60^{\circ}$ dan cos 60 adalah $1 / 2$ sehingga mereka menjawab bahwa $\mathrm{T}=1 / 2 \mathrm{~W}$.

Konsep yang ada pada gambar 4 adalah konsep kesetimbangan benda tegar, dimana pada sistem berlaku $\sum \mathbf{F}=0$. Siswa sering melupakan konsep dari kesetimbangan benda tegar, dan langsung menggunakan apa yang ada pada soal. Pada soal tertera sudut sehingga langsung digunakan $\mathrm{T}=\mathrm{W} \cos \theta$, namun hal tersebut dapat menyebabkan kesalahan hasil dari penyelesaiannya (Abdullah et al., 2015; Docktor et al., 2015; Kohl \& Finkelstein, 2008). 


\section{Kesalahan ketika Mengidentifikasi dan Menggambarkan Gaya yang Bekerja pada Sistem Kesetimbangan Benda Tegar}

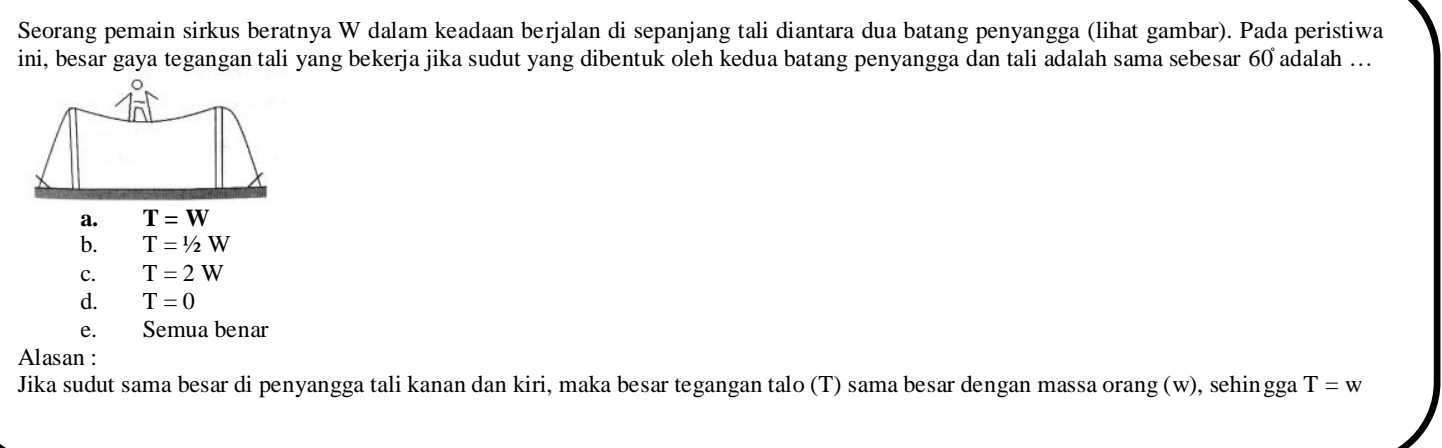

\section{Gambar 4. Salah Satu Contoh Soal dan Jawaban Pengidentifikasian Gaya Dalam Kesetimbangan Benda Tegar}

Dalam menyelesaikan permasalahan seperti gambar 4, diperlukan mengidentifikasi gaya-gaya yang terdapat pada sistem. Sistem terdiri dari orang, tali dan penyangga, dan gaya yang dapat diidentifikasi adalah gaya berat dan gaya tegangan tali. Gaya tegangan tali terdapat dari dua sisi, sisi kanan dan sisi kiri. Pada sebagian kasus tali sisi kanan dan sisi kiri akan membentuk sudut yang berbeda. Namun, pada soal gambar 4 sudut yang dibentuk adalah sama. Cara yang dapat dilakukan untuk menyelesaikan permasalahan di atas dengan memproyeksikan tegangan tali sisi kanan dan kiri searah horizontal dan vertikal. Jika tegangan tali sisi kanan digambarkan dengan $T_{1}$ dan tegangan tali sisi kiri disimbolkan dengan $T_{2}$, maka proyeksi untuk bidang horizontal masing-masing $T_{1} \sin \theta$ dan $T_{2} \sin \theta$, untuk bidang vertikal masing-masing $T_{1} \cos \theta$ dan $T_{2} \cos \theta$ (Flores et al., 2004; Maries \& Singh, 2013; Morphew et al., 2015; Shaffer \& McDermott, 2005). Kasus di atas bekerja pada bidang vertikal, dengan demikian masukkan ke persamaan matematis hukum I Newton $\sum \mathbf{F}=0$, bidang vertikal terdapat gaya berat dengan arah ke bawah, dan $T_{1} \cos \theta$ dan $\mathrm{T}_{2} \cos \theta$ memiliki arah ke atas. Diperoleh hasil $\mathbf{W}-\mathrm{T}_{1} \cos \theta+\mathrm{T}_{2} \cos \theta=0$, sehingga $\mathrm{W}=\mathrm{T}_{1} \cos \theta+\mathrm{T}_{2} \cos \theta$. Cos 60 adalah $1 / 2$, maka diperoleh $\mathrm{W}=\mathrm{T}$.

\section{SIMPULAN}

Berdasarkan hasil dan pembahasan di atas dapat disimpulkan bahwa siswa masih banyak melakukan kesalahan dalam mengidentifikasikan dan menggambarkan gaya yang bekerja pada satu permasalahan. Mengidentifikasi dan menggambarkan diagram gaya merupakan sesuatu yang sangat memengaruhi cara penyelesaian masalah. Dua hal tersebut sangat berkaitan erat, jika siswa mampu mengurai jenis-jenis gaya dengan baik, maka dengan mudah juga mereka menggambarkan diagram benda bebas yang ada.

Dalam penelitian ini diperoleh hasil bahwasanya masih banyak kesalahan yang terjadi pada siswa ketika menyelesaikan suatu permasalahan yang terkait hukum newton terutama dalam mengidentifikasi dan menggambarkan diagram gaya. Untuk mengurangi kesalahan siswa, siswa perlu dilatih kemampuan menggambarkan diagram dan mengidentifikasi gaya dengan model pembelajaran berbasis diagram gaya dan pembelajaran modeling instruction yang diduga mampu mengatasi siswa dalam pelajaran fisika terutama pada materi hukum Newton.

\section{DAFTAR RUJUKAN}

Abdullah, A. H., Abidin, N. L. Z., \& Ali, M. (2015). Analysis of Students' Errors in solving Higher Order Thinking Skills (HOTS) problems for the topic of fraction. Asian Social Science, 11(21), 133. https://doi.org/10.5539/ass.v11n21p133

Ayesh, A., Qamhieh, N., \& Abdelfattah, F. (2010). The Effect of Student Use of the Free-Body Diagram Representation on their Performance. Educational Research, 1(10), 505-511.

Barniol, P., \& Zavala, G. (2014a). Force, Velocity, and Work: The Effects of Different Contexts on Students Understanding of Vector Concepts Using Isomorphic Problems. Physical Review Special Topics - Physics Education Research, 10(2), 1-15. https://doi.org/10.1103/PhysRevSTPER.10.020115

Barniol, P., \& Zavala, G. (2014b). Test of Understanding of Vectors: A Reliable Multiple-Choice Vector Concept Test. Physical Review Special Topics - Physics Education Research, 10(1), 1-14. https://doi.org/10.1103/PhysRevSTPER.10.010121

Brookes, D. T., \& Etkina, E. (2009). "Force," Ontology, and Language. Physical Review Special Topics - Physics Education Research, 5(1), 1-13. https://doi.org/10.1103/PhysRevSTPER.5.010110

Cummings, K., Laws, P., Redish, E., \& Patrick, C. (2004). Understanding Physics is based on Fundamental of Physics. John Wiley \& Sons, Inc. 
Docktor, J. L., Strand, N. E., Mestre, J. P., \& Ross, B. H. (2015). Conceptual Problem Solving in High School Physics. 020106, 1-13. https://doi.org/10.1103/PhysRevSTPER.11.020106

Flores, S., Kanim, S. E., \& Kautz, C. H. (2004). Student Use of Vectors in Introductory Mechanics. American Journal of Physics, 72(4), 460-468. https://doi.org/10.1119/1.1648686

Heckler, A. F., \& Scaife, T. M. (2015). Adding and Subtracting Vectors: The Problem with the Arrow Representation. Physical Review Special Topics - Physics Education Research, 11(1), 1-17. https://doi.org/10.1103/PhysRevSTPER.11.010101

Ishimoto, M., Davenport, G., \& Wittmann, M. C. (2017). Use of Item Response Curves of the Force and Motion Conceptual Evaluation to compare Japanese and American Students' Views on Force and Motion. 020135, 1-15. https://doi.org/10.1103/PhysRevPhysEducRes.13.020135

Januarifin, D., Parno., \& Hidayat, A. (2018). Kesalahan Siswa SMA dalam Memecahkan Masalah pada Materi Hukum. (April 2018). https://doi.org/10.21067/mpej.v1i1.2292

Knight, R. D. (1995). The Vector Knowledge of Beginning Physics Students. The Physics Teacher, 33, 74-77. https://doi.org/10.1119/1.2344143

Kohl, P. B., \& Finkelstein, N. D. (2008). Patterns of Multipe Representation use by Experts and Novices During Physics Problem Solving. Physical Review Special Topics - Physics Education Research, 4(1), 1-13. https://doi.org/10.1103/PhysRevSTPER.4.010111

Maries, A., \& Singh, C. (2013). To Use or Not to Use Diagrams : The Effect of Drawing a Diagram in Solving Introductory Physics Problems. 282. https://doi.org/10.1063/1.4789707

Morphew, J. W., Mestre, J. P., Ross, B. H., \& Strand, N. E. (2015). Do experts and novices direct attention differently in examining physics diagrams? A study of change detection using the flicker technique. Physical Review Special Topics Physics Education Research, 11(2), 1-6. https://doi.org/10.1103/PhysRevSTPER.11.020104

Nguyen, N.-L., \& Meltzer, D. E. (2003). Initial Understanding of Vector Concepts among Students in Introductory Physics Courses. American Journal of Physics, 71(6), 630-638. https://doi.org/10.1119/1.1571831

Resbiantoro, G., \& Nugraha, A. W. (2017). Miskonsepsi Mahasiswa pada Konsep Dasar Gaya dan Gerak untuk Sekolah Dasar. Jurnal Pendidikan Sains, 5(2), 80-87.

Rosengrant, D., Van Heuvelen, A., \& Etkina, E. (2009). Do Students Use and Understand Free-Body Diagrams? Physical Review Special Topics - Physics Education Research, 5(1), 1-13. https://doi.org/10.1103/PhysRevSTPER.5.010108

Saepuzaman, D., Indonesia, U. P., Samsudin, A., Indonesia, U. P., \& Sutrisno, A. D. (2014). Diagnosis Kesulitan-kesulitan Siswa dalam Konsep Gerak dan Gaya ( Sebuah Penelitian Survey ). (June 2016).

Serway, \& Jewett. (2006). Physics for Scientists and Engineers. In Journal of College Science Teaching (Vol. 36). https://doi.org/013613923X

Shaffer, P. S., \& McDermott, L. C. (2005). A Research-Based Approach to Improving Student Understanding of the Vector Nature of Kinematical Concepts. American Journal of Physics, 73(10), 921-931. https://doi.org/10.1119/1.2000976

Wechsler, S. M., Saiz, C., Rivas, S. F., Vendramini, C. M. M., Almeida, L. S., Mundim, M. C., \& Franco, A. (2018). Creative and Critical Thinking: Independent or Overlapping Components? Thinking Skills and Creativity, 27(January 2017), 114122. https://doi.org/10.1016/j.tsc.2017.12.003 